ASSISTANT DIRECTOR. To work with Director in supervision and administration of a stafl of ninety, include 26 professionals. He/She will assist in development of policies and procedures; be responsible for automation acfivities: prepare grant requests; coordinate building repair and maintenance, assist in budget preparation and expenditures: represent the Director in his absence; plus other related assignments. Requirements: MLS from accredited library school: minimum of five years administrative experience in college or university library; training and/or experience in library automation operations: knowledge of A.V materials and uses thereof. Benefits: Salary of $\$ 15,000-\$ 16,000$ depending on experience; laculty rank and status; state retirement participation; insurance coverage; reduced tuition and other tringes. Applications accepted to November 10. Position will be filled as soon as possible alter that date. Send resume and references to Melvilie R. Spence, Director of Libraries, Bowl ing Green State University Libraries, Bowling Green, OH 43403. An equal apportunity employer.

HEAD OF REFERENCE. Business Administration and So cial Sciences Division. Directs reference services as wel as extensive collection of government documents. Duties inciude some book selection and servicing of biblio. graphic data bases. MLS and five years experience re. quired. Graduate degree in Social Sciences or docu ments experience desirable. Minimum salary $\$ 16,000$ Tweive month academic appointment, 22 days vacation, standard insurance, and State retirement. Send resume by December I, 1975 to Joseph Jerz Assistant University Librarian for Staff Development, University of North Carolina, Chapel Hill, NC 27514. An equal opportunity/ alfirmative action employer. Clatd be addressed to the Advertising Department. office belore the second of the month preceding publi cation of issue desired. Copy received after that time may be held for the next issue.

Telephone orders for classified advertising, while not encouraged because of the increased risk of copy error. will be accepted. Calls should be directed to Leona Swiech at (3/2) 944-6780. A confirming order should be mailed to the Advertising Department as soon as possible following the call, along with typewritten copy to be used in proofreading the ad.

Rate for classified advertising is $\$ 1.30$ per printed line.

\title{
POSITIONS WANTED
}

TEMPORARY POSITION ends November. Available immediately. MLS Canadian, 8 years experience in government/academic libraries. Strengths/experience in collection building, bibliographical activities, planning/policy library outreach programs, training staff, seminar/workshop presentations. Steadily increasing adminis. trative responsibilities. Special interest in official documents, legal materials, exchange programs and Reader Services. Will relocate in So. Ontario Ottawa/Montreal Maritimes, Thunder Bay, New England. Box 849, C\&RL NEWS, $50 \mathrm{E}$. Huron St. Chicago, IL 60611 .

\section{POSITIONS OPEN}

Acquisitions

ACQUISITIONS LIBRARIAN. Syracuse University seeks a Monographic/Serials Acquisitions Librarian for its new and highly automated main library. MLS from an accredited library school, reasonable experience in monographic/serials acquisitions and in automated systems in libraries necessary. Facility with one or more foreign languages desirable. Salary: \$11,256+ depending on experience. Apply to: R. Max Willocks, Assistant Director of Libraries, Syracuse University, Syracuse, NY 13210. An equal opportunity employer.

ACQUISITIONS. Assistant Librarian $(\$ 10,716-\$ 15,084)$ or Senior Assistant Librarian $(\$ 12,600-\$ 16,884)$. Both require second master's degree or progress toward same: latter requires two years experience. One or more languages. including (preferably) German. Supervision of three subprofessionals and of all bibliographical searching. Participation in selection. Request application form from Henry Madden, University Librarian. California State University, Fresno, CA 93740. An equal opportunity/ affirmative action employer.

LIBRARIAN. Administers the programs operations and services of Lockwood Library, the largest single unit of the University Libraries's system of SUNY at Buffalo. Lockwood serves the Humanities, Social Sciences and Education disciplines. The collection consists of over 900,000 volumes within a total appointed staft of over 70 FTE. Specific responsibilities include overall person nel utilization, collection development operational and budgetary coordination and development. Qualifications: ALA-accredited Master's Degree in Library Science. A minimum of 3 to 5 years experience in public service and collection development areas of a major academic library, with at least two years of experience managing a unit or department. Subject Master's Degree in the Social Sciences or Humanities is desirable. Salary: $\$ 18,000$ and negoliable, depending on experience and qualifi cations plus liberal fringe benefits. Faculty rank as Associate Librarian or Librarian. Please send replies to Uni. versity Libraries' Personnel Olfice, State University of New York at Buffalo, 308 Lockwood Library, Buffalo, NY 14214. An equal opportunity/affirmative action employer.

LIBRARIAN. Academy of Natural Sciences of Philadel. phia. Duties: Supervise main library; help with fund raising: select department acquisitions: prepare collections. BS degree in Science (Biology): advanced li. brary degree; five vears professional experience; reading knowledge of one foreign language. Closing date No vember I. Salary range: $\$ 2,000 \$ 14,000$. Forward cur riculum vitae to Ms. Aibertha C. Roberts LIM Depart ment Academy of Natural Sciences of Philadelphia, 19th and the Parkway, Philadelphia, PA 19103. Ar equal op portunity/affirmative action employer.

LIBRARY DIRECTOR. Eastern New Mexico University, state supported institution of over 4000 students oflering graduate and Education Specialist programs. Efficiently operating library with holdings approximating 250,000 and with a professional stalf of 12. Master's degree from an ALA-accredited library school required with addi tional graduate work preferred. Varied library experience with a minimum of five (5) years in administrative posi tions required. Faculty rank and salary, dependenf ypon qualifications with salary not less than $\$ 20,000$. Send resume including two references by December 1, 1975, to Miss Peggy $M$. Tozer, Chairperson. Search Committee, Eastern New Mexico University Library, Portales, N.M. 88130. An equal opportunity/affirmative action employer.

THE UNIVERSITY OF MICHIGAN. Assistant Head of Monograph and Cataloging Division, Technical Services Department. Assists with the training of stalf and the revision of cataloging in the Descriptive Cataloging 

records; assists the heads of the other units in the Division in training of stafl and revision of work as required: assists with the supervision of the Division. Graduate degree in library science, several years of professional cafaloging experience, knowledge of at least 3 principal European languages, demonstraled supervisory abilily. \$13,608-\$15,000. Write to Mrs. Lynn F. Marko Assistant for Personnel and Stafl Development. University of Michigan Library, Ann Arbor, MI 48104. The University of Michigan is a non-discriminatory, affirmative action employer.

ASSISTANT DIRECTOR FOR ADMINISTRATIVE SERVICES. Responsible for broad range of management areas including Research Developmenf Unit, Systems Development Unit, Personnel Office, and Business Office, Other assignments include coordination of planning activities, docu mentation of policies, equipment, facilities and collection and analysis of statistical data. Desired qualifications: Advanced deqree in library or intormation science: ad. ditional degree or graduale work in business administration or related areas. Record of varied and progressive assignments in librarianship and/or library administration. Ability to provide leadership and planning for the various units of this division and to coordinate their activities with the other divisions of the system. A record of research and publications. Position carries faculty rank and responsibilities. Salary: $\$ 20,000$ and up depending on qualifications and experience. Available January 1, 1976. Request application and detailed notice of vacancy from John Thomas, Personnel Officer. Libraries/Audio Visual Center, Purdue University, West Lafayette, IN 47907. Applications not accepted after November 30 1975. An equal opportunity/alfirmative action employer.

Cataloging

CATALOGER, Experience required. OCLC Participant. Serials, Medical and Academic materials. Central Process ing Division. Master's Degree in Library Science from an accredited institution required. Salary $\$ 12,000$. App with references and resume to Gerard B. McCabe, Director of University Libraries, Virginia Commonwealth University, 901 Park Ave. Richmond, VA 23284. An equal opportunity/affirmative action employer.

Multiple

Library, Platksburgh State University. (Professional staff 14. Collection 251000 volumes.) Two positions. (1) ASSOCIATE LIBRARIAN. Responsible for cataloging, acquisition, periodicals and government documents sections and personnel in technical services. Knowledge of advances in technology management and budget associates with technical services. Some weekend work. MLS, ALA ac. credited school, subject Master's and experience in aca demic library required. Tweive month salary $\$ 12,749$ $\$ 17,000$. (2) ASSISTANT LIBRARIAN. Responsible to head of technical services. Coordinate all acquisitions, supervise stafl, establish procedures for ordering library ma terials. Some weekend work. MLS, ALA accredited schoo relevant experience, and supervisory capabilities required. Subiect Master's desirable. Twelve month salary $\$ 9,000-$ $\$ 10,600$. Positions open February 2,1976. Send resume credentials and three relerences by November 14,1975 to Mrs. Anne Mirchell, Acting Director of Libraries Feinburg Library, Box 2200, State University of New York. Plattsburgh, NY |290|. An equal opportunity/alfirmative action employer.

Public Services

ASSISTANT UNIVERSITY LIBRARIAN FOR PUBLIC SERVICES. Responsibilities: Administration of Public Services Division including || Branch Libraries located on the Contral Campus with a total stalf of 73 including 28 professionals of which 15 are department heads; also shares responsibility for the general administration of the library, Qualifications: Must have MLS from ALA. accredited school and at least 5 years academic library experience including 3 years of administrative experience. Additional experience desirable. Minimum salary: $\$ 20,000$ but cammensurate with qualifications and experience. Submit resumes by January 15, 1976, to: Renee Evans, Universily of Southern California Library. Librarian's Of fice, University Park. Los Angeles, CA 90007.

REFERENCE/BIBLIOGRAPHER-Life Sciences. Academic vear appointment with faculty rank. Available November 1. Minimum salary $\$ 10,780$. ALA-accredited $M L S, 3$ years relevant experience and graduate degree in a life science or equivalent background/experience required. Duties include: assistance with and instruction in use of Library resources: data base searches development of bibliographic guides; selection; liaison with faculty. Full position description available on request. Send request by 11/15/75 to G. E. Parks, Dean, University of Rhode Island Library, Kingston, RI 0288I. An equal opportunity/af. lirmative action employer.

REFERENCE LIBRARIAN. The reference department includes general reference, government publications, ethnic studies, microform areas. Qualifications: Baccalaureate degree in science or mathematics; knowledge of foreign languages: ability to communicate and work with the public. A second masters, experience in an academic library and with computer assisted retrieval is desirable. Salary \$9,600-\$11,000. 12 month contract. Position avail able February I, 1976. Apply to Sidney Yen, Search Committee. The General Library, University of New Mexico $87|3|$

REFERENCE LIBRARIAN. General reference in a growing urban campus library. Interest in forma classroom library instruction, college teaching and library expe rience, second masters in science or social sciences al highly desirable. MLS from ALA accredited library schoo! necessary. Full faculty status including the responsibilities of research and publications. \$10,000 ten month an nual contract, excellent fringe benefits. Send vitae with references to B. Donald Grose, Director of Library Ser vices, Indiana University-Purdue University, 2101 Coliseum Blvd. East Fort Wayne, IN 46805. Application deadline November 15, 1975. An equal cpportunity employer.

HEAD REFERENCE LIBRARIAN. University Library. Responsible for coordination of all information services within the main library including: general information services and bibliographic guidance, document location and retrieval, computer-based citation and information retrieval services in conjunction with other appropriate library offices. Qualifications: MLS from an ALA ac credited institution. minimum five years experience as a relerence librarian in a recognized research library. Basic understanding of overall library functions and demonstrated abilify to organize and administer a $\mathrm{co}$. ordinated reference service required. Subject Master's and knowledge of one or more European languages high Iv desirable. Benefits: twenty-fwo working days vaca tion per year, TIAA-CREF, full faculty status, liberal fringe benefirs, salary $\$ 14,000-\$ 16,434$. Apply to: Robert Lee Caruthers, University of Louisville Library. Belknap Campus, Louisville, $\mathrm{KY} 40208$. An equal opporlunity affirmative action employer.

\section{Subject Specialists}

SYDNEY UNIVERSITY (AUSTRALIA) SYSTEMS OFFICER (LIBRARY). The Library requires a senior member of staff reporting to the Librarian to be responsible for the planning and development of manual and automated ibrary information systems, Existing systems include an on-line circulation system, catalogue card production. special reserve, and various specialized catalogues and lists. Responsibilities include the administration of li brary computer facilities and data entry activities. The Systems Officer will head a team consisting of two senor programmers, a documentation officer, and three data entry operators. Present equipment consists of a Data General $840 / 1200 \mathrm{~J}$ minicomputer system for circulation and data entry in the Library and a Cyber 72 at the Computing Centre. Preference will be aiven to those with library experience and prolessional library qualifications. Data processing experience is required. Salary will be within the range $\$ 13,017-\$ 14398$ (Australian) P.A. Applications giving full details of qualifications and experience and the names of two relerees should be sent to the Librarian. University of Sydney, 2006 N.S.W. by October 31 1975.

BEGINNING SCIENCE LIBRARIAN, Science Library, November I, 1975 (closing date, October 15, 1975). MLS from an accredited library school. Undergraduate degree in physical sciences, preferably biology or chemistry. 
Reading knowiedge of German and/or French desirable. Job description: provide readers' services to science community; provide liaison between Science Library and two science departments in matters of acquisition and public relations: assume managerial responsibility for a function such as acquisitions and serials or inter-library loan to be determined by applicant's interest and experience. Salary: $\$ 10,624$ for a 12 month contract. The appointment will be as a Visiting Instructor on a fixed three year term contract. Librarians at the University of Oregon have full faculty status. Nine month contracts are available. Write: H. W. Axford, University Librarian, University of Oregon, Eugene, OR 97403. An equal opportunity, affirmative action employer.

LIBRARIAN: Head, Science and Technology Department. Librarian needed to administer the Science and Tech. nology Department of Syracuse University Libraries. The eneumbent will supervise all the services, bibliographical reference and general, provided by the Department and maintain close liaison with laculty and students in the Sciences. A MLS from an accredited library school is required. At least 3 years experience in a major science library and demonstrated ability in supervision and management of a maior library organization is required. An undergraduate science major or live years experience in a major science library is preferred. Salary: $\$ 15,000+$ depending on qualifications. Send resume to $R$. Max Willocks, Assistant Director of Libraries, Syracuse University, Syracuse, NY 13210. An equal opportunity employer.

HUMANITIES BIBLIOGRAPHER. Responsible for development and control of collection in English and American literature and history since 1600 , and related fields. Qualifications: MLS: graduate study in appropriate field. Salary range: $\$ 11,472 \$ 24,672$. Apply belore December I, 1975, to Mr. Anthony Greco, Assistant University Librar ian, University of California, Los Angeles, CA 90024.

ASSOCIATE LIBRARIAN FOR TECHNICAL PROCESSES. Applicants should have master's degree from accredited school, several years of experience in L.C. cataloging and acquisitions or serials work in automated system, and ability to manage OCLC-like (SOLINET) system. Rank of Associate Professor beginning salary to $\$ 17,100$. One month annual leave, Blue Cross/Shield, choice of TIAA or State retirement. For more information write to Robert L. Balliot, University Librarian, Western Carolina University Cullowhee North Carolina 28723. Western Carolina University is a constituent institution of the University of North Carolina. An equal opportunity employer.

MUSIC LIBRARIAN. University of Colorado Library. The music library is a collection of 38,000 volumes and 48,000 recordings which serves the teaching and research needs of the College of Music and other disciplines at the University of Colorado. One important quality of candidates will be their demonstrated ability to work closely with instructors and students to interpret the music library as part of the educational process in a large university. Minimum salary (depending upon qualifications) $\$ 12,000$. Starting date: At latest January I, 1976. Requirements: Master's degree in Library Science, a subject degree in Music (or equivalenf experience in a music library) and five years of library experience. Apply to John Lubans. Jr. Assistant Director Public Services, University of Colarado Library, Boulder. Colarado 30302. 303-492-751I. An equal opportunity/affirmative action $\mathrm{em}$ ployer.

HEAD LIBRARIAN WANTED: The Center of Planning and Economic Research in Athens (Greece) wishes to hire a librarian, holding at least a Master's Degree in Library Science, and with practical experience in libraries. The person in question should be fluent in Greek and will be placed as head of the library. Monthly salary range $\$ 600$ to $\$ 700$. Candidates should submit their applications to: Center of Planning and Economic Research Attn: Mr. G. Calligas, 22 Hippokratous 5t. Athens 144, Greece.

INTERNATIONAL DOCUMENTS LIBRARIAN: The University of Arizona is seeking a professional librarian to assume responsibility for a growing collection of international publications. The International Documents Librarian will select pertinent materials, initiate processing procedures, and provide reference service for the col lection. This librarian, as a member of the Documents Department at the University of Arizona Library, will report to the Head Documents Librarian and will also provide some reference service for U.S. Government publications. Applicants must be graduates of an ALA accredited library school. Qualifications include experience in an international documents collection and/or relevant course work in library school, and reading knowledge of French. A subject background in economics or political science is desirable and a reading knowledge of Spanish would be helpful. Librarians at the University of Arizona have faculty status but 12-month appointments with 22 days per year of paid vacation and a standard package o holidays and other fringe benefits. Salary depends upon experience, but the minimum for a beginning profes sional librarian is $\$ 9,600$. Applications will not be ac cepted after November 20, 1975. Send resumes and in quiries to Mary Dale Palsson, Assistant Librarian for Pub lic Services, University of Arizona Library. Tueson, AZ 85721. An equal opportunity/allirmative action employer.

ASSISTANT EDUCATION LIGRARIAN-Morris Library Southern Illinois University at Carbondale. The Library is a member of the Association of Researeh Libraries and Center for Research Libraries. Assistant Education Librarian to provide reference service and related activities in Education/Psychology Division library. AP proximately one-half time at the education reference desk, while remaining time is devoted to supportive relerence activities and collection development. Qualifications: Fith-year library degree from ALA-accredited library school. Second master's in psychology or edu cation is required: one modern foreign language. Two to-three years' experience in university reference position highly desirable. Salary and rank will depend on education and experience but minimum $\$ 13,200$. Participation in University Retirement System of lllinois, state paid life, hospital and surgical insurance. Voluntary participafion in tax deferred annuity program. 37 -hour work week: 25 vacation days: 60 calendar days sick leave per contract year: 12 -month appointment. Position open with application deadline 20 November 1975. Send letter of application to Sidney E. Matthews. Assistant Director, Morris Library, Southern Illinois University at Carbondale, Carbondale, Illinois 62901 . An equal opportunity. affirmative action employer.

REGIONAL CAMPUS TECHNICAL SERVICES LIBRAR|AN Serves eight regional campus librarians on five regional campuses of The Ohio State University. Responsible for ccordinating the centralized technical services to the regional compuses from Main Library on the Columbus campus. Acts as liaison between the regional campus librarians and the Quick Editing (QUE) division (OCLC unit) of the Libraries. Does all original cataloging for regional campuses, using Library of Congress classifi. cations. Expected to plan and execute a system for cataloging non-bcok materials. Supervises the acquisition process and bookkeeping for regional campus libraries. Facilitates borrowing from main campus collections. provides ILL locations for items not owned by OSU and checks reference sources not locally owned for regional campus librarians. Staff includes library as sistants and student assistants. Works closely with the Regional Campus Technical Services Steering Committee. Graduate degree from ALA-accredited library school. Three or more years of acceptable library experience. including some technical service experience. Cataloging experience, knowledge of Anglo-American cataloging rules. Library of Congress classification and subject headings desirable. Administrative ability, strong com mitment to service. Salary up to $\$ 12,500$ annually: salary and laculty rank commensurate with qualifications. Expected to meet university requirements for research and publications. Send resume to: Personnel Librarian. The Ohio State University Libraries, 1858 Neil Avenue Mall, Columbus, $\mathrm{OH} 43210$. An equal opportunity/affirmative action employer.

For out-of-print issues of College \& Research Libraries News, write to University Microfilms, 300 North Zeeb Rd. Ann Arbor, MI 48106. Issues are available one year after date of publication. 


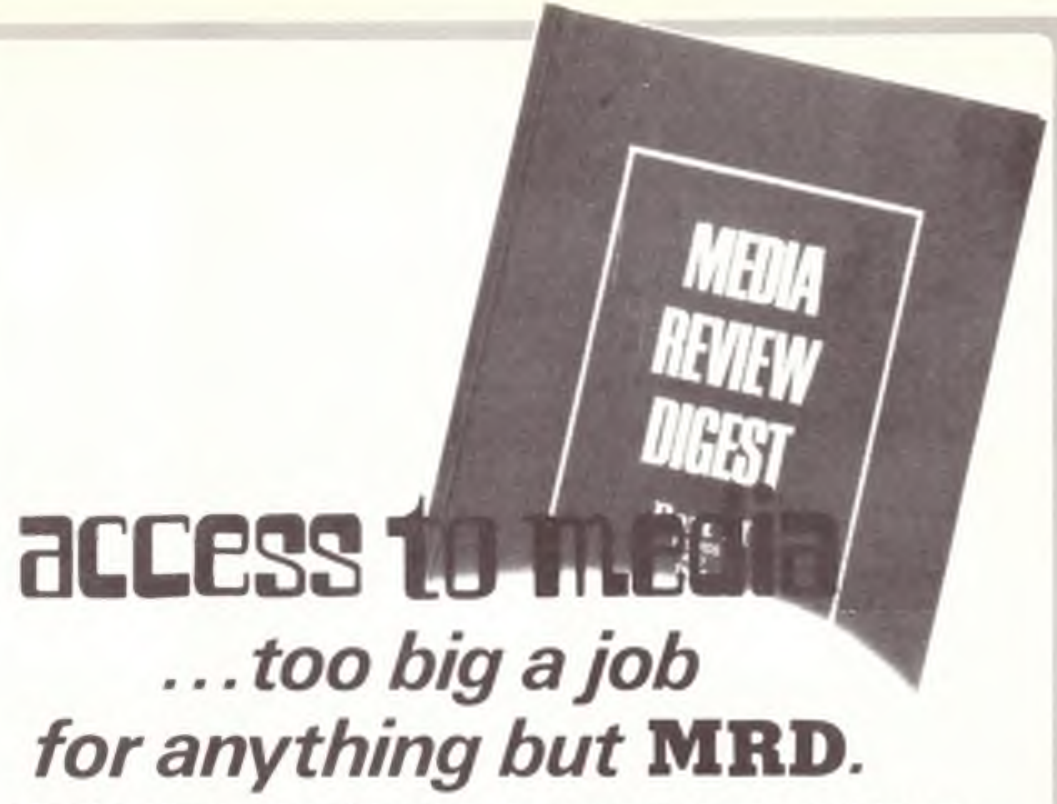

MEDIA. That's a lot of territory to cover when you need to use something special. Particularly if you don't know which medium to use, let alone what is available in each.

Unless you know the right place to look.

MEDIA REVIEW DIGEST is the right place to look, for nonbook media review and acquisition data on anything from feature films to games and educational toys.

MRD researches media in 204 critical review sources from PLAYBOY to RELIGION TEACHER'S JOURNAL and comes up with the hard facts every quarter - plus extras like content summaries for feature films, complete cataloging data in both Dewey and Library of Congress formats, awards and prizes section, frequent quotes from significant reviews for quicker selection, a directory of producers and distributors for one-stop acquisition, thorough cross-indexing...more than we could even list here. But don't just take our word for it. Check out the exhaustive review of MRD in the June Booklist REFERENCE AND SUB. SCRIPTION BOOKS REVIEWS section, page 1087.

Then consider putting MRD to work in your media center.

\section{MEDIA REVIEW DIGEST} from. pierian presS 5 ann arbor, michigan 


\section{NOW THB BRE ARI new volumes now ready in Gale's American Literature, English Literature. and World Literatures in English Information Guido Serios}

AMERICAN FICTION, 1900-1950: A Guide to Information Sources. (Vol. 1 in the Series) Edited by James Woodress, Professor of English, University of California at Davis. xxii $+260 \mathrm{pp}$. Intro: Annotations; Index. ISBN 0.8103-1201-8, \$18.00.

A bibliographical guide to the literary scholarship of the entire period, and to the fiction of and criticism on the 44 most important writers of the era. Following the General Bibliography are Individual Bibliographical Essays on each author that cover bibliography and manuscripts, works of fiction, editions and reprints, biography, and criticism.

ENGLISH PROSE, PROSE FICTION, AND CRITICISM TO 1660: A Guide to Information Sources. (Vol. 2 in the Series) Edited by S.K. Heninger, Jr., Professor of English, University of British Columbia. $x+255 p$. Preface: Annotations: Index of Authors and Editors. ISBN 0-8103. $1233-6,518.00$.

Includes all major writers of the era plus minor writers who produced notable works. The annotated entries are arranged in 12 categories: General. Religious Writings, Historical Writings, Essays, etc. Each section first lists secondary works, followed by a chronological arrangement of primary works.

THE LITERARY JOURNAL IN AMERICA TO 1900: A Guide ro Information Sources. (Vol. 3 in the Series) Edited by Edward E. Chielens, Assistant Professor of English. Detroit College of Business. vi + 197pp. Intro.; Annotations, Apps.; Index. ISBN 0-8103-1239-5. \$18.00

Reviews the literary periodicals of New England. the Mid-Atlantic States, the South, and the West, with a special appendix on Edgar Allan Poe, Each regional chapter is divided into sections on general studies and individual periodicals.
AMERICAN FICTION TO 1900; A Guide fo Information Sources. (Vol. 4 in the Series) Edited by David K. Kirby, Associate Professor of English, Florida State University. vi + 260pp. Intro.: Annotations: Index. ISBN 0.8103-1210-7, \$18,00.

Two parts: General Aids includes handbooks, bibliographies and checklists, periodicals and serials, and general critical studies; Individual Authors lists and describes the principal works by and the criticism on 41 authors

ENGLISH DRAMA TO 1660: A Guide to Information Sources. (Vol. 5 in the Series) Edited by F. Elaine Penninger. Professor of English and Chairperson of the Department, Westhampton College, University of Richmond. $v i+520 p p$. Foreword: Annotations; Index. ISBN 0-8103. 1233-9. \$18.00.

This selective. annotated bibliography directs students of Medieval and Tudor drama to primary and secondary sources, including rare books and microfilm. Covers general studies on the progressive stages of Medieval drama, and deals with the works of 34 major playwrights.

ENGLISH-CANADIAN LITERATURE TO 1900: A Guide to Information Sources. (Vol. 6 in the Series) Edited by R.G. Moyles, Associate Professor of English, University of Alberta. 280pp Intro: Annotations; Index. ISBN 0-8103-1222-0. $\$ 18.00$

Provides annotated listings of both primary and secondary material in such categories as. General Reference Guides, Literary Histories and Criticism, Major Authors, Minor Authors, Selected Nine. teenth-Century Journals, etc. 